\title{
THE OLD-AGE RESERVE ACCOUNT AND ITS ECONOMIC IMPLICATIONS
}

\author{
Grorge M. ModLIN*
}

\section{Provisions Affecting the Account}

The Old-Age Reserve Account created by Title II of the Act is one of the most interesting and significant features of the social security program. Commencing in I937 Congress is authorized to make yearly appropriations to the account "of an amount sufficient as an annual premium to provide for the payments required under this title, such amount to be determined on a reserve basis in accordance with accepted actuarial principles. ..."1 No mention is made in this title as to the source of these appropriations, but Title VIII of the Act provides for two new taxes which take effect January 1937, and the proceeds of these taxes are to be paid directly into the general funds of the Treasury. One tax is levied upon the wages of all the employees covered under Title $\mathrm{II}_{,}^{2}$ and the other, equal in amount, is imposed upon their employers. ${ }^{3}$ The annual appropriations that Congress is authorized to make to the Reserve Account presumably will tend to correspond to the receipts from these two taxes. Constitutional considerations made it inexpedient to provide a more direct relationship between contributions and appropriations to the Account.

As payment of old-age benefits will not begin until January 1942, the appropriations to the Account will accumulate for five years with no disbursements from it, except relatively small amounts for death benefits. Moreover, it is estimated that not until about 1980 will annual disbursements equal the annual receipts from both appropriations and interest on the funds invested in the Reserve Account. It is believed the Account at that time will amount to about 47 billion dollars, and that thereafter it will remain at approximately this figure. The estimates of the growth of the Account on the page following appear in the Senate Report on the bill. ${ }^{4}$

The investment of the funds in the Reserve Account, as provided in Title II of the Act, must be made by the Secretary of the Treasury "only in interest-bearing obligations of the United States or in obligations guaranteed as to both principal

- B.A., 1924, Wake Forest College; M.A., 1925, Ph.D., 1932, Princeton University. Instructor and Assistant Professor of Economics, Princeton University, since 1928. Contributor to economic periodicals.

${ }^{1}$ Social Security Act of Aug. 14, 1935, 49 STAT. 620, Tit. II, \$201 (a).

Id. $\$ 80 \mathrm{r}$.

Id. $\$ 804$.

'Report of the Senate Committee on Finance, Sen. Rep. No. 628, 74th Cong., Ist Sess. (1935) 9. 
Estimated Growth of the Reserve Account (in millions of dollars)

\begin{tabular}{|c|c|c|c|c|}
\hline $\begin{array}{c}\text { Fiscal Year } \\
\text { ending June } 30\end{array}$ & $\begin{array}{l}\text { Appropriation } \\
\text { for reserve }\end{array}$ & $\begin{array}{l}\text { Interest } \\
\text { on reserve }\end{array}$ & $\begin{array}{c}\text { Benefit } \\
\text { payments }\end{array}$ & $\begin{array}{c}\text { Balanec } \\
\text { in reserve }\end{array}$ \\
\hline${ }^{\ldots}, \ldots, \ldots, \ldots, \ldots$ & 255.5 & 0. & I.9 & $\begin{array}{l}253.7 \\
76.7\end{array}$ \\
\hline 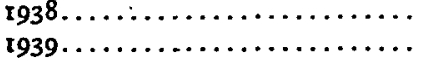 & $\begin{array}{l}513.5 \\
518.5\end{array}$ & $\begin{array}{r}7.6 \\
23.0\end{array}$ & 1.2 .5 & $1,299.5$ \\
\hline $1940 \ldots$ & 662.2 & 38.8 & 22.0 & $x, 973.6$ \\
\hline г941 $\ldots \ldots \ldots \ldots \ldots \ldots \ldots \ldots \ldots \ldots \ldots$ & 807.2 & 59.2 & 29.7 & $2,810.3$ \\
\hline r942....... & $8 \mathrm{r} 4.8$ & 84.4 & 52.8 & $3,656.6$ \\
\hline r943........................ & 970.0 & 109.8 & 94.2 & $4,642.1$ \\
\hline$\ldots \ldots \ldots \ldots+\ldots, \ldots$ & $I, 126.6$ & 139.3 & 142.9 & $5,765.1$ \\
\hline r945....................... & $1,137.0$ & 173.0 & I91.2 & $6,883.9$ \\
\hline 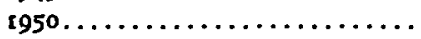 & $1,783.3$ & 371.5 & 505.5 & $14,031.7$ \\
\hline โ955. & $1,861.2$ & 615.8 & 887.8 & $22,115.7$ \\
\hline$\ldots \ldots \ldots, \ldots, \ldots$ & $1,939.1$ & 844.2 & $x, 379.9$ & $29,543.9$ \\
\hline ז965.. & $2,016.9$ & $1,040.9$ & $x, 844.0$ & $35,898.5$ \\
\hline 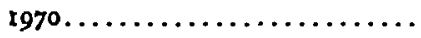 & $2,094.8$ & $1,210.9$ & $2,303.5$ & $41,366.7$ \\
\hline 1975 $\ldots \ldots \ldots \ldots \ldots \ldots \ldots \ldots \ldots$ & $2,172.7$ & $\mathrm{I}, 34 \mathrm{~T} .8$ & $2,872.1$ & $45,368,3$ \\
\hline 1980 & $2,180.5$ & $1,406.0$ & $3,5 \times 1.3$ & $46,942.7$ \\
\hline
\end{tabular}

and interest by the United States." These securities may be (I) ordinary obligations purchased in the open market at the market price to yield at least 3 per cent, (2) ordinary obligations purchased on original issue at par to yield at least 3 per cent, or (3) special obligations issued by the 'Treasury exclusively to the Reserve Account and bearing an interest rate of 3 per cent. The ordinary obligations held in the Account may be sold at the market price, but the special obligations may be redeemed only by the Treasury at par. ${ }^{\circ}$

\section{The Nature of THE Account}

The contributory taxes levied on employees and employers will, like other forms of internal revenue, flow into the general funds of the Treasury. The yearly appropriations by Congress to the Reserve Account must be invested by the Secretary of the Treasury in the manner indicated. If the Secretary purchases obligations in the open market for the Account, the amount of federal securities held by the public will be diminished. However, the total federal debt outstanding will not be reduced but merely shifted from the public to the Reserve Account. In this way, a part of the interest payments on the federal debt will be credited to the Account on the securities held therein, and such interest receipts likewise will be invested in approved obligations.

If the Secretary invests the funds of the Reserve in special obligations, as may well be the case, he will issue special 3 per cent bonds to the Account and credit to the general funds of the Treasury the cash received for the bonds. By this method of investment it is clear that proceeds from the contributory taxes will pass from the general funds of the. Treasury through the Reserve Account and be returned again to the general funds. The Account, therefore, will consist of federal securities that

${ }^{8}$ Social Security Act, $520 x$ (b).

'Id. S201 (c). 
represent the obligation of the government to pay interest and, when necessary, to liquidate a portion of the principal. Although it may be considered unusual for the assets of a reserve in the Treasury to be held in the Treasury's own securities, the underlying basis of these assets is the taxing power and credit of the federal government. Any system of social insurance presumes financial responsibility on the part of the government.

The Reserve Account is thus simply a bookkeeping device within the Treasury. Its principal purpose is to indicate the existence of a formal claim against the federal government for funds that will be devoted to the payment of old-age benefits. The existence of such an account gives a degree of permanence and contractual certainty to the program, thus tending to preclude any alterations in the contributory tax schedules or in the scale of benefits as changes occur in economic conditions or political propensities.

\section{Significance of a Reserve}

The significance of the Reserve Account depends primarily upon the viewpoint from which it is considered: To the Treasury Department it will appear largely as an accounting and actuarial procedure, for the Account will represent a yearly record of the liability assumed by the federal government for the future payment of old-age benefits. The contributing employee will regard the Reserve as a "fund" that he has helped to accumulate, and from which he will expect benefits after he has retired. From the standpoint of the general public the principal importance of the Reserve Account lies in its effects upon taxes, current economic conditions, and standards of living. Finally, one of the most significant aspects of the Account is the effect that it will have upon the distribution of the burden of the old-age program.

In a contributory old-age insurance system the size of the reserve depends, among other factors, upon the size of benefits to be granted to workers who will retire within a few years. As their contributions will be insufficient to provide them with an adequate annuity upon retirement, the payment of a reasonable annuity will result in their receiving some "unearned" benefits. There are three general methods for meeting the heavy liability incurred if the existing older workers are to receive a decent annuity. First, a pay-as-you-go, cash-disbursement policy might be followed. In that case, the government assumes from the outset the burden of paying the unearned annuities to older workers. Consequently, smaller contributions are sufficient to provide the younger employees with benefits in later years. This was, in general, the method Great Britain adopted in rg25.

Second, the government may assume this accrued liability to the older workers, but may postpone the actual payment of this subsidy until the future, when receipts from contributions will be insufficient to meet the annual benefit payments. The program recommended to Congress by the Committee on Economic Security was based on this principle.? The Committee proposed that the contributory taxes on

'For a statement of the Committee's proposal, see Comantree of Economic Securrty, Report to the President (1935) 29-34. 
employees and employers begin at I per cent (instead of 2 per cent, as in the enacted law) and that they increase by I per cent each five years (instead of each three years) until r957, when a maximum tax of 5 per cent on payrolls would be imposed. It was estimated that such a schedule of taxes would result in a maximum reserve of approximately 15 billion dollars by $1965^{.8}$ In that year, however, the contributory taxes would not be sufficient to cover the disbursements for benefits, and governmental contributions would commence. This subsidy might be considered to represent interest on the amounts withdrawn from the Reserve Account and paid in unearned annuities to the older workers during the early years of the program. Thus, instead of commencing the federal subsidy when the first benefits are to be paid in 1942, the contributions of the younger employees and their employers would be used for that purpose. The postponed federal subsidy, begun in 1965, would increase gradually to a maximum of about a billion and a half dollars in 1980 and continue thereafter at that amount. ${ }^{9}$

The third method of meeting the cost of unearned annuities for the older employees is to provide a funded reserve. This was the policy adopted by Congress upon the insistence of the Secretary of the Treasury, who wanted the plan to be "self-sustaining." Under this method the federal government will bear no part of the cost of the benefits to those older workers who will retire shortly after I942. Instead, the burden has been placed upon younger wage-earners and their employers through the imposition of contributory taxes higher than necessary to meet their own annuities. In the absence of a direct governmental subsidy a huge perpetual endowment reserve must be accumulated so that the interest on the reserve, in combination with future contributory taxes, will be sufficient to meet all benefit payments.

The belief is somewhat prevalent that the subsidy under the plan proposed by the Committee on Economic Security would be roughly equivalent to the interest charges which, under the present Act, will be paid by the government from general taxation. While from the standpoint of the general tax-payer in the distant future there is some apparent justification for this view, it should be pointed out that under the adopted plan a large amount of the federal debt may, in effect, be shifted gradually into the Old-Age Reserve Account. Thus, the interest accruing on securities in the Account will be but a continuation of the interest charges that otherwise would be payable on federal obligations in the hands of the public. After about 1965 , when benefit payments to the retired aged exceed the appropriations of contributory taxes to the Accojnt, a portion of the interest paid into the Reserve Account will be disbursed to beneficiaries, and to that extent it may be considered as an indirect subsidy at the time. However, this interest should be regarded more accurately as

\footnotetext{
${ }^{3}$ This estimate was based upon the additional coverage of farm labor and domestic servants. With these groups excluded, the reserve as recommended would amount to about $11 \frac{1}{2}$ billions.

The maximum subsidy with farm labor and domestics excluded was estimated to reach approximatcly I.I billion dollars.
} 
the payment for the former use by the government of the funds appropriated from contributory taxes to the Account. If the heavier contributory taxes were not imposed, the general tax-payer, after about Ig8o, when it is believed the Reserve Account will reach its maximum, would be taxed to pay the direct subsidy to the Account in addition to the interest charges on the government obligations, whether in the Account or in the hands of the public.

\section{Distribution of the Burden}

Statements are frequently encountered which intimate that the cost of the benefits can be transferred to future generations, or on the other hand that the existence of a huge reserve involves too great a burden upon future generations. In this connection there are two fundamental principles that should be emphasized. First, each generation pays the cost of supporting the aged of its time. The goods and services produced in each period sustain the population of that period, for goods and services can seldom be produced in one period and consumed in another, except through the growth of productive capital goods. ${ }^{10}$ Second, the accumulation of a reserve in the Treasury merely determines the division of the burden between the contributory tax-payers and the general tax-payers at any one period of time. When the reserve is being amassed, purchasing power will be transferred from employees and their employers (or from consumers through higher prices) to other groups. These groups will be composed of the recipients of federal expenditures made from those funds derived from contributory taxes. ${ }^{11}$ Later, purchasing power will be diverted to the aged beneficiaries, partly from the pockets of general tax-payers (through interest payments on the reserve) and partly from the incomes of contributory taxpayers. The amount that each of the two groups will pay at any particular time will depend largely upon the size of the Reserve Account.

\section{Some Effects of a Large Reserve}

\section{Political Difficulties}

It is unfortunate that the Act does not connect more closely the contributory taxes with the payment of old-age benefits. As a consequence, there is a possibility that political considerations may upset the adjustment between contributions and benefits. Not only would this prevent the accumulation of a reserve of this dimension, but it may preclude the establishment of any satisfactory reserve. In the first place, Congress may not continue to levy the yearly taxes according to the proposed schedules, particularly when those taxes reach the higher rate levels. Moreover, Congress will be called upon to appropriate a sum increasing from around 500 million to two billion dollars a year to a Reserve Account that will be mounting steadiy. Under such circumstances it will be difficult indeed for the Treasury to explain to Congress the need for amassing such a tremendous reserve. The existence of this large reserve might cause a reduction in the tax rates, which would be more justifiable, or might

\footnotetext{
${ }^{10}$ This possibility is discussed, infra, p. $227 . \quad{ }^{11}$ See infra, p. 227.
} 
result in the appropriation of the contributory tax revenue to various governmental purposes without first establishing corresponding credits in the Reserve Account. The legal necessity for separating the collection of the contributory taxes and the use of such funds for old-age benefits, therefore, may lead eventually to a weakening of the insurance principle in the system.

\section{Fiscal Problems}

Should the program be carried out as projected, a number of problems will have to be faced. The resulting increase in federal revenues by 500 million to two billion dollars a year may necessitate a radical readjustment of governmental financial policies. Unless federal expenditures increase proportionately, the new contributory taxes on low-intome groups will be used to retire the public debt or general taxes would need to be reduced. Despite the inequity of such a policy of debt reduction, it would improve the credit position of the Treasury. This would facilitate future borrowing, which might become necessary should a portion of the Reserve Account need to be liquidated to meet benefit payments.

If the yield on federal bonds should continue below 3 per cent, special 3 per cent obligations will have to be deposited in the Account. 'The excess of the guaranteed 3 per cent interest rate above the lower market rate would constitute, in effect, a subsidy to the Reserve Account. Owing to the wide demand for federal securities by various investment groups, it is highly probable that a gradual retirement of the federal debt would cause prices of government bonds to rise to a considerable premium. On the other hand, if market interest rates should increase so that the yield on government bonds exceeds 3 per cent, the Secretary of the Treasury might purchase federal bonds in the market for the Reserve Account in order to sustain government credit. However, it is more likely that he would issue special 3 per cent obligations to the Account, and if possible retire outstanding high-yield bonds with the funds received in return therefor, so as to preclude larger appropriations for interest charges. In any event, the credit of the government will not be subjected so frequently nor so fully to the test of the open market. This may produce an unwholesome effect upon federal financial policies. It is doubtful whether the operation of such a large reserve can be absorbed into the normal administration of the Treasury without serious disturbance. ${ }^{12}$

\footnotetext{
12 These difficulties may be accentuated somewhat by the existence and supervision of the Unemployment Trust Fund established under Title IX, $\$ 904$, of the Social Security Act. Although the Trust Fund differs from the Reserve Account in being held in the form of a trust by the Secretary of the Treasury, nevertheless the provisions for investing and liquidating the Fund are almost identical with those of the Account. However, even in prosperous periods it is 'probable that the Trust Fund will never exceed three billion dollars. The yearly receipts into the Fund will be much smaller than the appropriations to the Old-Age Reserve Account, and should not create any serious additional problems for the Treasury. In the future, however, a period of business depression may necessitate the liquidation of a portion of the Reserve Account at the same time that a heavy drain upon Unemployment Trust Fund will require the disposal of large quantities of its securities, which are also government obligations. This might result in a serious decline in the market price of federal bonds, but it is more likely that the Treasury would collaborate with the Federal Reserve authorities to prevent such a consequence. In all probability the existence of these two
} 


\section{Capital Accumulation}

A more theoretical problem, but one which may have serious economic consequences, is the effect that the accumulation of a huge reserve will have upon the relationship between consumer spending and investments in capital goods. If the program continues in operation as projected, the appropriations to the Reserve Account from the contributory taxes and from general taxation (as interest on the reserve) will come principally from purchasing power that otherwise would be spent for consumers' goods.

The way in which the government disposes of these funds will determine the ultimate effect upon savings. In addition to the payment of relatively small benefits during the early decades, there are three general purposes to which the Treasury might devote the proceeds: ( 1 ) to retire the federal debt, (2) to defray the ordinary current expenses of the government, or (3) to meet extraordinary expenses and prevent the budget from becoming unbalanced. The effects of these applications of the revenue are, respectively, to divert purchasing power directly to investors, to reduce general taxes, or to make unnecessary an increase in taxes. Therefore, federal disbursements of the new contributory tax receipts will either increase investments in capital goods or prevent their reduction. It can be concluded that, in the years during which the Reserve Account is being accumulated, there will be a net diversion of national income from spending for consumers' goods to investment in producers' goods.

After about I980 the disbursements to beneficiaries will absorb the entire sum entering the Account from annual appropriations and from interest on obligations held in the Account. Consequently, there will be no transfer of national income from consumer spending to investment; rather there may be some diversion of income from tax-payers who might otherwise save the funds to the beneficiaries who undoubtedly will spend them for consumers' goods.

\section{National Productivity}

In the future the standard of living of the aged groups unquestionably will be much higher than it is at present, and, moreover, they will constitute a much larger proportion of the population than now. Either this will reduce the standard of living of the remainder of the population or the productivity of the country must increase sufficiently to compensate for the difference. The latter will result only if there is continued technological progress, if the capital equipment of the country is increased, or if labor efficiency is stimulated, so that per capita production is expanded.

There is every indication that technical improvements will continue, with or without a social security program. Furthermore, the existence of a greater degree

governmental funds will necessitate a degrec of coopperation between the Treasury and the Board of Governors of the Federal Reserve System that may have an important bearing upon the control of commercial bank credit. 
of economic security for the wage-earners of the country should be expected to lessen the fears and anxieties that result from the prospect of dependence and poverty in old age. By affording a guaranteed protection against this hazard of industrial employment, the old-age insurance system should prove to be an important factor in stimulating the productive efficiency of our industrial workers. The impetus given by old-age insurance to the retirement of superannuated employees will have a similar effect, partly through accelerating the promotion of younger employees.

The extent to which a large Reserve Account will contribute to the expansion of the capital equipment of the country depends principally upon (a) how private business profits are affected and (b) how the federal government spends its money. There appear to be at least three ways in which business profits may be affected. First, the excise tax on payrolls may somewhat reduce immediate profits, though in the long run the tax will probably be shifted either forward to consumers or backward to the employees. Thus it would have little effect ultimately on profits and production. Second, the reduction in consumer spending may tend to have a depressing effect upon business profits in the consumer-goods industries in the near future. In the third place, a decline in interest rates resulting from increased saving should reduce costs of production, improve profit possibilities, and thus stimulate borrowing and an expansion of capital equipment.13 The eventual result would be more capital per worker and presumably an increase in future production, brought about by the investment of enforced contributions for future annuities on the part of present low-income groups.

The expenditure of the contributory taxes by the government may also affect the future productivity of the country. If the Treasury utilizes the new revenue to retire the outstanding public debt, the funds will be transferred to former owners of federal securities, who presumably will re-invest the proceeds in productive enterprise. As a large portion of the federal debt is held by banks, to the extent that they reduce their holdings of government securities their cash reserves will be increased and they, likewise, will probably substitute in their portfolios other investments in productive enterprise. If, on the other hand, the Treasury uses the new revenue to meet other governmental expenses, the effect on national productivity will depend on the purposes to which these funds are appropriated. The funds may be spent ( $\mathrm{x}$ ) for consumptive purposes, such as government salaries, unemployment relief or old-age assistance, ${ }^{14}$ (2) for non-productive capital goods, such as battleships or munitions, (3) for productive capital goods such as public works, highways, and flood control. This third type of expenditure probably will increase national pro-

13 With lower interest rates and higher labor costs there will be some stimulus to the introduction of labor-saving machinery and a pressure on employers to reduce wages (and thus shift the pay-roll tax back to the employees).

16 The appropriation of funds by Congress to the states for old-age assistance under Title I of the Social Security Act should not be confused with appropriations to the Reserve Account for old-age benefits. It should be clearly understood that the funds appropriated to the Account, after being exchanged for special Treasury obligations issued to the account, revert to the general funds of the Treasury and can then be 
ductivity and widen the tax base. Both (2) and (3) will stimulate production in capital goods industries, whereas the first type of expenditure will merely compensate for the consumer spending contracted previously as a result of the contributory taxes.

Númerous adjustments to a changing price structure will be necessary, and difficulties probably will be experienced by some employers and employees. The higher the contributory tax rates, and consequently the larger the Reserve, the less easily can the necessary adjustments be effected. However, business profits probably will not be unduly depressed, particularly if the inauguration of the program coincides with a period of generally prosperous business conditions. Once the Reserve Account is fully established and business has become adapted to the new conditions, the flow of considerable purchasing power from the several contributing groups to the retired beneficiaries should be maintained fairly easily. In fact, as the latter group will spend practically all of their income for consumers' goods, a stabilizing influence will be exerted that will serve as a cushion to prevent extreme declines in prices and production. This would be particularly effective if some of the purchasing power were derived, through the liquidation of securities in the Account, from funds that otherwise would have been saved but not invested-a situation that usually exists during periods of depression.

\section{Desirability of a Reserve}

In considering whether an old-age insurance reserve is desirable and necessary, a distinction should be drawn between a large funded reserve, such as that provided by the Act, and a small reserve sufficient merely to meet unpredictable contingencies. A large funded reserve is neither necessary nor desirable, whereas a small contingency reserve is essential.

As already indicated, a large funded reserve may (I) cause an unfair distribution of the burden between contributory tax-payers and general tax-payers, (2) complicate the fiscal policies of the Treasury, (3) create economic maladjustments between saving and spending, and (4) probably lead to political interference with the relationship between contributory taxes and old-age benefits. In addition, such a large reserve is not necessary to achieve the objectives for which it is to be created. One of the primary purposes of a reserve is to secure an equitable distribution of the burden of the system by requiring participants to contribute toward the benefits they will receive when the retirement age is reached. Despite the fact that the accumulation of a fully-funded reserve based on sound actuarial principles is essential in private old-age annuity plans, such is not the case in social-old-age insurance. The basis of a social program is the taxing power of the government, and there is no necessity for creating a perpetual endowment in order to divide, during any period, the

used for any authorized purpose, including grants for old-age assistance. If, however, such grants are made from the general funds, and appropriations corresponding to contributory taxes are not credited to the Reserve Account, a great injustice would be done to the contributing employees for, in effect, they, rather than more able, higher-income tax-payers, would be financing the federal old-age assistance program. 
burden of the system between the contributory tax-payers and the general tax-payers. Governmental contributions from general tax revenues can as well be made directly to the Reserve Account as indirectly through appropriations for interest on federal bonds held in the Account.

A second purpose of a reserve is to represent on the books of the Treasury the true fiscal position of the government with respect to the liability it has assumed under the Act. But to levy high contributory taxes and to accumulate such a huge reserve merely to accomplish this accounting objective seems altogether unnecessary.

In the third place, an essential purpose of a reserve is to enable the system to meet various eventualities that may arise. But a huge reserve is not necessary to accomplish this end. However, because of the possibility of such future exigencies, it is extremely desirable that a relatively small contingency reserve of from five to fifteen billion dollars be accumulated. During periods of business depression receipts from both contributory taxes and general taxes would decline. As benefit payments would continue undiminished, heavier taxes would be necessary if no reserve existed. In such a situation, some of the securities held in a reserve could be sold in the open market to investors who are usually in search of safe investments during such periods. In addition, a small contingency reserve is advisable in order to meet unexpected or unpredictable demands upon the system. Some factors which might cause an unexpected drain are: errors in the estimates of population trends, changes in mortality rates, a possible lowering of the retirement age, shifts in and out of covered employment, and variations in labor conditions and wage rates, such as a falling wage level over a long period.

Furthermore, the possibility of political interference would be lessened by the absence of a large reserve and by the lower schedule of contributory taxes. This would also give the contributors more assurance that the relationship between their contributions and their benefits would not be disturbed. Moreover, the Treasury could manage a small reserve without being forced to distort its normal tax and credit policies. Finally, because of the federal subsidy that would be necessary, a smaller reserve and lower contributory tax rates would cause a more equitable distribution of the burden involved in paying unearned benefits to eligible workers soon to retire. It would seem, therefore, to be the part of wisdom to amend Title VIII of the Act by lowering the contributory tax rates before a large reserve has been accumulated. Otherwise, an indispensable piece of social legislation may encounter difficulties that will seriously impair its operation. 